\title{
Status pozůstalých v současné společnosti
}

\author{
Monika Suchánska \\ Ústav antropologie, Př́rodovědecká fakulta, Masarykova univerzita, Vinařská 5, 60300 Brno \\ Do redakce doručeno 14. března 2016; k publikaci přijato 4. října 2016
}

\section{THE STATUS OF BEREAVED IN CONTEMPORARY SOCIETY}

ABSTRACT Since the beginning of $20^{\text {th }}$ century dominates rather restrained approach to death and the last things of man in general. Some of the authors speaks directly about death taboo. To this condition contributes medicalization, individualism and secularization on one hand and conservatism of funeral agencies on the other. Funeral ritual is no longer viewed as an important rite of passage and is often completely eliminated. This study deals with current status of bereaved in contemporary society. What does it mean to be bereaved, what types of behavior are expected from people with this status, how their close friends and family treats them and what kind of help they search for.

KEY WORDS death; bereaved; funeral; taboo; bereavement

\begin{abstract}
ABSTRAKT Od počátku 20. století převládá v západní společnosti spíše rezervovaný přístup ke smrti a posledním věcem člověka obecně, někteří autoři mluví př́mo o tabuizaci smrti. K tomuto stavu přispívají jak medikalizace smrti, individualizace a sekularizace společnosti, tak i konzervativnost oblasti pohřebnictví. Pohřební obřad již není vnímán jako důležitý přechodový a odlučovací rituál a často bývá zcela eliminován. Tato studie pojednává o tom, jak tento stav ovlivňuje postavení pozůstalých v současné společnosti. Věnuje se tomu, co to znamená být pozůstalý, jaké chování se od lidí s tímto statutem očekává, jak k nim přistupuje jejich okolí a jaké formy pomoci vyhledávají.
\end{abstract}

KLÍČOVÁ SLOVA smrt; pozůstalí; pohřeb; tabuizace; truchlení

\section{SMRT SKRYTÁ, VYHOŠTĚNÁ ČI PŘEVRÁCENÁ?}

Dnes se v souvislosti se smrtí nejčastěji mluví o její tabuizaci, odsunutí na okraj zájmu, vyhoštění ze společnosti. Gorer již v padesátých letech přirovnal tehdejší prrístup ke smrti $\mathrm{k}$ někdejší atmosféře panující kolem sexuálních témat. Podle něho jedno tabu ve společnosti vystřídalo druhé (1955, 50). Podle Waltera $(1990,33)$ dnes smrt není tabu, tedy něco př́tomné, o čem se nemůže mluvit nebo jen pomyslet na to. Podle něho smrt dnes není př́itomná, spíš jí není připisována velká důležitost než, že by byla potlačována, je skrytá spíš než zakázaná. Známý vyhýbající se pozůstalému na ulici to nedělá proto, že by nemohl o smrti mluvit, pouze nenachází způsob jak to udělat.

Otázkou je také významnost úmrtí jedince pro společnost. Šiklová $(2013,15,17)$ se také přiklání k tomu, že smrt dnes není tabu, pouze není žádnou velkou událostí. Lidé umírají ve vysokém věku, kdy už pro společnost nejsou tak významní, navíc zvyšující se samostatnost seniorů oslabuje rodinné vazby. Fyzické smrti dnes zároveň často předchází smrt sociální, kdy člověk zejména při dlouhé institucionální péči již přerušil své kontakty s jinými lidmi a pro okolí je na jisté úrovni mrtvý (Vágnerová 2007 in Špatenková et al. 2014, 34).

Na naše dnešní pojímání smrti měli nejvýraznější vliv proměny myšlení na počátku 20. století. Do té doby, konkrétněji do první světové války, smrt jedince hluboce zasahovala celé společenství. O mrtvé pečovali př́buzní, navštěvovali jejich hroby a o pozůstalé se starala rodina a přátelé, smrt měla veřejnou a společenskou povahu. Způsob umírání a postoje ke smrti se však v tomto období výrazně a rychle proměnili, soukromé se vyčlenilo oproti veřejnému a vzniklo to, čemu Ariès $(2000,317)$ říká převrácená smrt. Narůstaly obavy 
z toho, že vědomí blížící se smrti nemocnému přitíží a tak začali nejbližší umírajícímu o jeho stavu lhát, zakrývat nevyhnutelný konec. Okruh pozůstalých kolem umírajícího se také zmenšoval a na smrt obecně se pohlíželo jako na něco nechutné, špinavé, něco co je potřeba skrýt. Vyzdvihovala se ošklivost umírání v kontrastu s krásnou smrtí známou z předchozího století.

Také místo umírání se změnilo, přesunulo se $\mathrm{z}$ domovů do nemocnic, které byly v té době ještě i symbolem mravnosti (Ariès 2000, 329). Pokrok medicíny i techniky dokázal snížit úmrtnost ve společnosti a přesvědčil nejbližší prŕbuzné, že odevzdání umírajícího do péče lékařů je to nejlepší, co pro něj můžou udělat. Sami se tak připravili o možnost doprovázet jej na jeho poslední cestě a tím započalo umírání v osamění. Pozorujeme jej od 30. let a v 50. letech byl tento styl zcela běžný.

Pozůstalí měli tedy plnou důvěru v lékaře, jejichž hlavním úkolem bylo zachraňovat životy za každou cenu a smrt co možno nejvíce oddalovat. Umírající odevzdával svůj osud do rukou nejbližších a ti ho předávali lékařuom. Smrt tak byla vnímána jako selhání lékařské péče a umírající sám do poslední chvíle předstíral, že vlastně neumírá. To se od něj i očekávalo, měl do poslední chvíle společně s lékaři věřit $\mathrm{v}$ porážku smrti. Pojem krásná smrt $\mathrm{v}$ této době znamená umřít ve spánku.

Těmito změnami v myšlení a praktickém přístupu se umírání institucionalizovalo a byrokratizovalo, nad jeho průběhem měl kontrolu pouze personál, nikoliv sám umírající či jeho nejbližší. Ti, se snaží o to, aby umírající necítill úzkost svého stavu, aby necítil, že umírá (Ariès 2000, 334).

Model smrti vycházející z její medikalizace a uzavírání do nemocnic dotvořila víra v to, že rychle se rozvíjející technika smrt odstraní úplně (Ariès 2000, 346). Dnešní člověk tedy může mít pocit, že smrti je možné uniknout, protože tomu díky schopnostem medicíny tak někdy doopravdy je. Smrt je tedy v jistém smyslu ochočená, spoutána a kontrolována institucemi (Přidalová 1998, 5). Keller (1997 in Špatenková et al. 2014, 22) stručně rozdělil vývoj př́stupư ke smrti na instinktivní, rituální a institucionalizovaný, přičemž současný stav zařazuje mezi druhý a třetí stupeň.

S institucionalizací péče o umírající se objevuje i profesionalizace péče o mrtvé. Pohřební služby v této oblasti nahradily církev. Přejaly však pouze péči o zesnulé, nikoliv o pozůstalé. $\mathrm{V}$ českém prostředí zaměstnanci pohřebních služeb nepovažují emocionální pomoc pozůstalým za důležitou a zároveň jí nevnímají ani jako jeden z úkolů, který by mělo poslední rozloučení splnit (Špatenková et al. 2014, 228-229). Zároveň se ve svém jednání s pozůstalými snaží zachovávat pietu, co mnohdy zřetelně kontrastuje $s$ jasně komerčním nastavením těchto služeb. Výsledkem může tedy být pocit falešnosti (Kostelníková 2012, 52).

Zaměstnanci pohřebních služeb, jako i hrobníci či správce pohřebiště, přitom přicházejí do kontaktu s pozůstalými v první fázi jejich zármutku. Komunikace těchto pracovníků s truchlícími je proto obzvlášt důležitá a její zásady jsou obsaženy i v etickém kodexu Cechu hrobnického (Stejskal, Šejvl 2011).

\section{POSMRTNÝ ŽIVOT}

Víra v pokračování existence po smrti je důležitým prvkem při pozorování proměn vztahu pozůstalých ke svým mrtvým. $\mathrm{V}$ tomto směru sehrála důležitou roli tzv. citová revoluce $\mathrm{v}$ období romantismu, pro které je příznačná př̀edstava věčného koloběhu, shledání se s blízkými po smrti a smrt samotná je přitažlivou a v jistém smyslu i krásnou (Ariès 2000, 213).

Touha živých spojit se s blízkými zesnulými byla velice silná a $\mathrm{v}$ Americe tyto snahy vytvořili půdu pro vznik spiritizmu, který se následně rozšíril i do Evropy. Pozůstalí díky těmto praktikám nahliželi do záhrobí a ujištovali se o pokračování existence duší nejbližších (Ariès 2000, 192). Davies (2007 49) nazývá seance svátostí věčných vztahů a výrazem intuitivní ač neurčité podoby lásky, vzpomínky a naděje. Většinou byly tyto aktivity pro pozůstalé důležité krátce po smrti a neměli dlouhodobý charakter. Zároveň seance představovaly jakousi okamžitou pomoc pozůstalým, narozdíl od vzdáleného cíle, který jim nabízela víra.

Vzpomínky na zesnulého byly hlavním rysem vztahu ke smrti pro toto období. Uchovávány byly naprríklad v podobě pramenu vlasů zesnulého či v medailonku s jeho podobiznou. Místem vzpomínání byl samotný hrob, u kterého se plakalo, rozjímalo a modlilo. Hluboké citové vazby byly také vyjadřovány na náhrobcích. Hrob podporoval vnímání nepřetržitosti v rámci rodiny a hřbitov pak $\mathrm{v}$ rámci obce a lidstva. Lze mluvit př́mo o jakémsi kultu mrtvých (Ariès 2000, 255).

Péče pozůstalých o zesnulého se však netýkala jen zachování jeho památky na tomto světě. Skrze modlitby se snažili zajistit blízkým spásu a přízeň na onom světě, na rozdíl od pozdně středověkého období, kdy byla tato pozornost soustředěna pouze na sebe sama, na svou vlastní smrt.

Od 18. století tedy pozorujeme hluboké citové propojení živých s mrtvými a pozůstalí prožívají odchod blízkého člověka velmi intenzivně. I když byla ztráta milovaného člověka pro pozůstalé bolestivá, nevedla ke strachu z ní. Byla považována za krásnou a přitažlivou, protože vše pozemské přesahuje. Dnes je koncept nebe vnímán spíše v terapeutickém významu s odkazem na přetrvávající mezilidské vztahy (Davies 2007, 63).

$\mathrm{V}$ českém prostředí se dnes hlásí $\mathrm{k}$ nějakému náboženství asi třetina lidí. $Z$ nevěřící části populace věří v posmrtný život v nějaké formě asi každý desátý člověk. Podle Nešporové (2013, 67, $73,102)$ pro to, aby byly pohřební obřady funkční je potřeba sdílet skrze ně symbolické světy, náboženské nebo sekulární, srozumitelné a smysluplné pro ty, kteří se rozloučení účastní. Př́ležitostí uplatnit tyto symboly v obřadu posledního rozloučení je smuteční řeč či prostředí, ve kterém se tento akt odehrává. $\mathrm{V}$ rámci všeobecné profesionalizace pohřebnictví se do rukou cizího člověka dostal i smutečnní projev. Ten vznikne ve většině prrípadů pouze záměnou osobních údajů o zesnulém v jakési šabloně, která neobsahuje žádné odkazy na transcendenci, týká se pouze života zesnulého. Pak takový projev působí prázdně, frázovitě a odosobněně (Nešporová 2013, 192; Suchánska 2014, 45). Symbolika v architektuře obřadních síní (obr. 1) také nemusí být obecně srozumitelná nebo může diktovat konkrétní pocity zamýšlené těmi, kteří tyto stavby vytvářejí (Walter 1990, 187). 


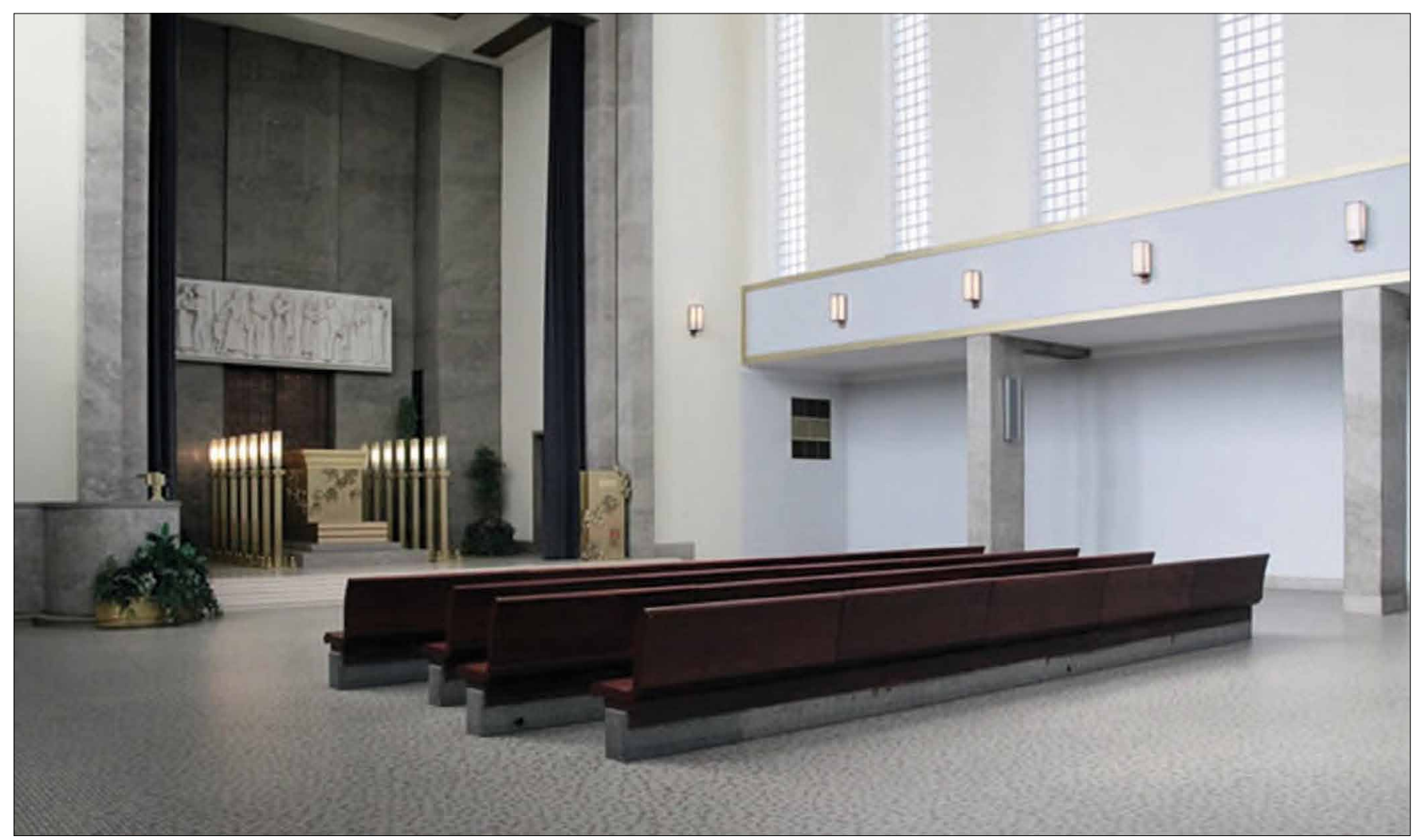

Obr. 1. Velká obřadní síň, Krematorium Strašnice. Zdroj: http://www.pohrebni-sluzba-atropos.cz/stat/foto/sine/16-velka-strasnice-MX.jpg

\section{OBJEVENÍ POZŮSTALÝCH}

Jak je již zmíněno výše, od počátku 20. století panuje kolem posledních věcí člověka jistá rezervovanost. V 60. letech se však navzdory tomu objevují také první snahy upřít pozornost na závěrečnou etapu života-umírání a začíná se formovat hospicové hnutí. To se soustředí nejen na zdravotní stav umírajícího, ale vnímá ho jako komplexní osobnost a neopomíjí ani jeho sociální vazby a spiritualitu (Davies 2007, 77).

Podmínky, ve kterých člověk umírá, se počínají zlepšovat zejména vlivem snah psychologů či sociologů. Také lékaři se více otevírají, začínají své pacienty informovat o jejich stavu a dělit se tak o odpovědnost. Vủbec poprvé se výzkumu toho, co umírající prožívají, věnovala americká lékařka Elisabeth Kübler-Rossová. Upozornila na to, že tabuizace smrti přitěžuje jak umírajícímu tak lékařskému personálu, který vnímá smrt pacienta jako své selhání (Kübler-Ross in Nešporová 2013, 16). Také Norbert Elias, německý sociolog, zdůraznil v charakteru umírání 20. století zejména samotu provázející člověka na lůžku a označil ji za slabost rozvinutých společností (Elias 1998, 8). Feldmann takovou smrt nazývá dekontextualizovanou a depersonalizovanou (Feldmann 2004 in Špatenková et al. 2014, 28).

Po přesunutí pozornosti na umírající už nebylo možné dále ignorovat ani jejich nejbližší, tedy dřív nebo později pozůstalé. Dobře to ilustruje aplikovatelnost modelu různých fází, kterými prochází umírající i na to, co prožívají pozůstalí: šok, popírání, hněv, deprese a konečné vyrovnání se se situací (Špatenková et al. 2014, 131-132).

Podle Waltera $(1990,48)$ je na jedné straně dobré, že se díky takovému modelu pozůstalí či umírající ujistí, že to, co prožívají je $\mathrm{v}$ pořádku. Na druhé straně upozorňuje na to, že nám to může dodávat pocit, že smrti rozumíme a získali jsme kontrolu alespoň nad tím, co jí předchází a co po ní následuje. Kübler-Rossová přinášela tyto poznatky v době, kdy už byla péče o umírající profesionalizována a lidem obecně chyběla osobní zkušenost se smrtí. Proto její zjištění mohlo tyto znalosti lidem zprostředkovaně doplnit. Zároveň však jaksi určují, co by měl jedinec cítit a Davies $(2007,37)$ nazývá takovéto zobecňování prožívání přímo nebezpečným.

\section{ZDROJE POMOCI}

Truchlení je přirozenou reakcí na ztrátu blízkého a bez něj není možné akceptovat tuto událost. Dưležité je chápat toto prožívání jako proces a ne stav i když může trvat celá léta (Špatenková et al. 2014, 41-42).

Truchlení mělo i v minulosti soukromou povahu, bylo však propojeno s náboženskými, osobními nebo etnickými rituály. Naproti tomu dnes je truchlení spíše hodnoceno dle určitých kritérií podle toho, co je považováno za funkční nebo dysfunkční. Jsou tu tedy přítomna jistá očekávání ze strany společnosti nebo odborníků a to může vést a vyhrocovat pocit 
bezmoci pozůstalých, pozměnit jejich přirozené chování. Obzvlášt' v tom případě, bereme-li v úvahu přítomnost vžitého myšlenkového vzorce dělat věci správně (Walters in Sutcliffe, Guinevere and Cornish 1998, IX).

Při dnešním institucionálním modelu péče o umírající je to právě lékař, kdo jako poslední s nimi přichází do kontaktu a je prvním v kontaktu s pozůstalými. Podle Kupky (2014, 125-126) by rozhovor s pozůstalými měl probíhat v klidném a bezpečném prostředí a měl by na něj být vyhrazen dostatek času. Dále předpokládá, že dobře zvládnutý rozhovor ze strany zdravotníků může usnadnit proces truchlení na straně pozůstalých.

Nejčastěji se v případě vyrovnávání se se ztrátou blízké osoby uplatňuje mechanizmus svépomoci, kdy si truchlící snaží pomoct sám. Tato schopnost zvládat náročné životní situace se také nazývá coping a zahrnuje jak geneticky podmíněný potenciál jedince, tak i volbu strategií. Dalším zdrojem neformální pomoci je také vzájemná pomoc, kdy je zaangažována rodina pozůstalého, jeho prátelé, sousedi nebo jiná komunita lidí (Špatenková et al. 2014, 133-134).

Úskalí vzájemné pomoci tkví v tom, že silné emoční reakce po ztrátě blízkého nabourávají u pozůstalých pocit vlastní identity a integrity a také vztahy s jinými lidmi. Každý člen rodiny truchlí jinak a vzájemná pomoc tak nemusí být efektivní, či vůbec možná. Rodina jako celek se potýká s novou situací, čímž je ohrožena i její funkčnost (Špatenková et al. 2014, 135). Často se nejbližší pozůstalých můžou uchylovat k prázdným frázím typu Netrap se tím! nebo Všechno musí jednou skončit... (Špatenková 2013, 12). Podle Waltera (1990, 27) tato neschopnost širší komunity pomoci pozůstalým přímo souvisí s tím, že dnes, zejména ve městech, je smrt skryta v nemocnicích či pohřebních službách a lidé tak neumí reagovat na chaos, který prožívají ti, kteří jsou ztrátou nejvíce zasaženi. Chaos, který je potřebný k tomu, aby mohly být ustanoveny nové vzorce chování pozůstalých. Čím intenzivněji je smrt ve společnosti odsouvána, tím menší je schopnost jejích členů spontánně reagovat na chování pozůstalých a tím dřive se očekává ukončení truchlení (Kast 2015, 14, 56).

Pokud nenalezne truchlící oporu v rodině či okruhu známých, může mu být nápomocný zdravotnický personál, duchovní, člověk, který prošel tím, co ted' prožívá on sám či svépomocné skupiny. Podle Kubičckové je také žádoucí, aby lidé v pomáhajících profesích rozšiřovali své kompetence i o účinnou pomoc pozůstalým (Kubíčková 2001 in Špatenková et al. 2014, 137). Mezi pracovníky pohřebních služeb byl pozorován spíše odmítavý postoj vưči rozšiřování svého vzdělání, odůvodněný vlastním nezájmem či nedostatkem času (Rychlíková 2013, 88).

Zdrojem formální pomoci může být kvalifikovaný poradce pro pozůstalé, který systematicky a se supervizí doprovází klienty od fáze umírání blízké osoby, při přípravě posledního rozloučení a dále v zpracovávání zármutku (Špatenková et al. 2014, 140). Klíčovým úkolem poradenství pro pozůstalé pak je uvědomit si skutečnost ztráty a její význam, dopady a ireverzibilitu prostřednictvím rozhovorů o tom, co se odehrálo (Špatenková 2013, 42).
Právě absence rozhovorů o zesnulém a jeho smrti stojí, podle Waltera (1990, 156), za narůstající potřebou poradenství pro pozůstalé. Není k tomu vyhrazen čas na pohřbu, který se často ani neuskuteční, stejně jako pohřební hostina, blízcí či vzdálenější známí se pozůstalým vyhýbají.

\section{OSAMOCENÉ TRUCHLENÍ}

Dnešní způsob truchlení bychom tedy mohli označit jako privatizovaný, každý truchlí sám v sobě, pozůstalí odmítají i projevy soustrasti. Zármutek ostatních není pro ně srovnatelný s tím, co prožívají oni sami. Truchlení přestalo být kolektivní záležitostí, chybí ritualizované chování, které by podporovalo jednotné naladění všech členů společnosti. Navenek nepř́ítomný zármutek však nemusí být důsledkem lhostejnosti lidí, nýbrž zamítavého postoje společnosti.

Podle Arièse $(2000,340)$ společnost smrt vyobcovala a pozůstalí se ocitají v jakési karanténě (Šiklová 2013, 97). Individualismus dnešní doby na jedné straně velebí jedinečnou hodnotu každého $\mathrm{z}$ nás a na druhé straně truchlícího izoluje a v masové produkci uniformních posledních rozloučení naši jedinečnost ničí (Walter 1990, 62). V takovéto izolaci je pro pozůstalé prakticky nemožné vytvářet si nový vztah k životu, znovu nalézat jeho smysl (Kast 2015, 15).

Tento př́stup $\mathrm{k}$ pozůstalým je od svého počátku na sklonku 20. století odborníky považován za nebezpečný. Smrt blízkého je hlubokým otřesem a je potřeba zacelit rány, které způsobil, zvnitřnit osobnost zesnulého a naučit se žít dál bez něj. Důraz psychologové kladli i na společnost, která má být v tomto procesu jedinci nápomocná. Do 18. století však tato pomoc skupiny fungovala velice dobře a překonávání žalu proto nebylo tak problematické jako od 20. století. Bylo tomu tak i díky vnímaní smrti jako něčeho, co může zasáhnout kdykoliv a kohokoliv. Život byl kolektivnější a člověk měl tak více citových vazeb. Ztráta blízkého člověka byla sice bolestná, ale nedosahovala té intenzity jako v dnešní individualizované společnosti, kdy je člověk úzce citově provázán jen s několika málo lidmi. Soudržnost společenství po ztrátě jednoho člena byla znovu nastolena scházením se a návštěvami pozůstalých. Pohřební obřady měly i svou veselou povahu, která na jejich konci vystřídala zármutek (Ariès 2000, 342).

Dnešní člověk může také velmi lehce propadnout tzv. naučené bezmoci. Ta se objevuje po ztrátě blízké osoby v těch situacích, ve kterých by byl za jiných okolností aktivní ted' již zesnulý. Pozůstalý po jeho smrti musí přebrat odpovědnost $\mathrm{v}$ těchto momentech do vlastních rukou, naučit se nové věci, přehodnotit svou identitu (Davies 2007, 38).

V psychologii se dnes také klade důraz na posttraumatický rozvoj osobnosti, tedy na to, jak může prožívání ztráty blízké osoby vyvolat pozitivní změny $\mathrm{v}$ životě pozůstalých (Mareš 2012, 13). Také Davies $(2007,89)$ navrhuje vytvoření takové spirituality smrti, která by umožňovala pozůstalým vyjádření emocí, sebereflexi a v konečném důsledku pozitivní zhodnocení této zkušenosti. 


\section{PASIVNÍ DIVÁCI}

Do role pozůstalého je podle Špatenkové $(2014,166)$ člověk veřejně uveden skrze pohřební rituál, který je tak pro něj rituálem přechodu. Pohřeb dnes tedy nese význam spíše pro pozůstalé, kterým by měl přinést útěchu, naplnit jejich osobní, společenské, emocionální a náboženské potřeby (Jackson 1963 in Yoder 1986, 152).

Do 20. století byly pohřební obřady orientovány na zesnulého a byly úzce spjaty s představami o posmrtném životě. At’ už $\mathrm{v}$ církevním kontextu či $\mathrm{v}$ kontextu romantických představ o pokračování života $\mathrm{v}$ domově na nebesích. $\mathrm{V}$ následujícím období byl smrti jako veřejné události upřen její slavnostní charakter a proměnila se v soukromý akt pro nejbližší rodinu (Ariès 2000, 334).

Pohřeb musí být, podle Waltera (1990, 113), označením důležité události, konce jednoho lidského života. Pokud tedy dnes poslední rozloučení selhávají, je to proto, že nesplňují toto kritérium. Není na nich znát, že se jedná o cosi důležitého. Hlavní úlohou pohřbu je pomoct uvědomit si realitu úmrtí, dovolit nám začít truchlit a adaptovat se na nový život. To vše se děje skrze znovuznázornění smrti v podobě rakve zajíždějící za oponu či její spouštění do země. Velmi účinné může být také vystavování těla, naproti čemu zavřená rakev v nás může zanechat pocit nereálnosti. Za důležité autor považuje, aby pohřeb prŕtomné nejdřív zavedl do jakéhosi emocionálního limba, kde si uvědomí realitu ztráty a pak je $\mathrm{z}$ něho také vyvedl zpátky do života. To vše se musí zároveň odehrát v bezpečném prostředí (Walter 1990, 132, 180).

Podle Nešporové je poslední rozloučení ritualizovaným kolektivním jednáním pozůstalých, při kterém se loučí se zesnulým a klíčovou roli zde hraje právě kolektivní charakter události a smysl, který mu aktéři připisují (Nešporová 2013, 101). Ze širší perspektivy je skrze rituál možné poukázat na významné společenské hodnoty a vyjádřit to, jak sám sebe vnímá ten který národ. Pohřební rituál se pak dále přímo dotýká samotné lidské přirozenosti (Davies 2007, 55), podtrhává skutečnost a definitivnost smrti (Worden 1982 in Špatenková et al. 2014, 167).

Funkční pohřební rituál na jedné straně potvrzuje naše ideály a na druhé straně je zpochybňuje, přemostuje propast, je na pomezí povrchní reality a hloubek, které nás daleko přesahují. Tak jako nedělní fotbalový zápas nám připomíná, že kromě práce je potřeba i odreagovat se, pohřeb nám má připomenout, že lidská existence není pouze o žití. Pohřeb je pro nás šancí nahlédnout do méně příjemných dimenzí reality a pak pokračovat v životě s tím, co jsme v nich objevili (Walter 1990, 35).

Také pohřební hostina může zásadně ovlivnit prožívání pozůstalých. Je v první řadě projevem solidarity, propojuje účastníky a dává jim šanci povídat si mezi sebou (Walter 1990, 152). Společné jídlo po pohřbu je také jedním $\mathrm{z}$ rituálů, se kterým se může člověk identifikovat bez ohledu na společenskou prŕíslušnost. Jako každodenní aktivita je symbolem toho, že pozůstalí budou ve svém životě pokračovat dál. Při jídle můžou vznikat společné plány pozůstalých a jejich nej- bližších do budoucna $\mathrm{v}$ neformální atmosféře, což zvyšuje pravděpodobnost budoucího kontaktu a činí ho méně ostýchavým (Yoder 1986, 155-156).

Co se týče samotného zemřelého, Walter $(1990,13)$ připomíná, že lidé vždycky vnímali mrtvé tělo jako odpudivé, jako něco na pomezí dvou světů, něco co vypadá jako člověk, ale již jím není. Náboženství a rituály pomáhali tuto situaci lépe uchopit a poskytovali živým ochranu. Dnes za péči o mrtvé platíme cizím lidem a prostředí či obřady v síních krematorií nenabízejí nic, $\mathrm{v}$ čem bychom mohli tuto ochranu najít. Koho však můžeme $z$ tohoto stavu vinit, když ne sami sebe. My zaplatíme profesionálům za to, že vše vezmou do svých rukou místo nás, budeme to mít rychle za sebou i když s konečným pocitem nereálnosti, umělosti a odosobnění. Podoba pohřbů se podle autora tedy změní $\mathrm{k}$ lepšímu, až když začneme přemýšlet o tom, co vlastně chceme a začneme o tom přemýšlet dlouho předtím, než to budeme v praxi potřebovat.

Dnešní pohřební firmy se snaží zajistit bezproblémový průběh rozloučení, proto zůstávají v zaběhnutých kolejích a působí konzervativně. Pro pozůstalé je v těžkém emočním rozpoložení také jednodušší přijmout tento předem daný formát obřadu a přizpůsobit si $\mathrm{v}$ něm pouze minimální individualizované prvky jako vlastní hudbu či poezii (Davies 2007, 63-64). Výběr vlastní hudby jako snahu personalizovat jinak uniformní obřad dokládá také Maiellův $(2005,45)$ výzkum v českých obřadních síních.

Podle Waltera $(1990,143)$ však nemůže pohřeb plnit svou funkci, dokud jsou pozůstalí v roli pasivních diváků. Proto vidí nebezpečí $\mathrm{v}$ dnešním modelu péče o zesnulé $\mathrm{v}$ rukou profesionálů. Za vhodné považuje rozložení povinností v komunitě pozůstalých, přičemž vedení příprav a obřadu by nemělo spočívat na nejbližších příbuzných, kteří jsou ztrátou nejvíce zasaženi.

V České republice dnes panuje poněkud neobvyklá situace, ve světovém měřítku zcela výjimečná. Až jedna třetina všech kremací proběhne bez jakéhokoliv obřadu, $v$ Praze pak více než jedna polovina. V moravské části republiky naopak výrazně převažuje pohřbívání s obřadem (80-90\%), zhruba $\mathrm{v}$ jedné tř̌etině pohřbů se jedná o inhumaci (v Praze jsou to jen $3 \%)$. Tento stav je ovlivněn zejména silnějším vlivem tradic a prŕíklonem ke křestanství (Nešporová 2013, 186, 194). Současné sekulární pohřební obřady v síních krematorií jsou pozůstalými vnímány jako chladné a neosobní, projevy řečníku jako prázdné a rychlost vypravování pohřbu připomíná běžící pás (Suchánska 2014, 44).

Vnímaní role pohřbu blíže ilustrují odpovědi respondentů z výzkumu Olgy Nešporové (2013, 197-202). V první řadě byl jimi pohřeb vnímán jako běžná forma rozloučení pozůstalých s mrtvým a nikdo z dotázaných se nedomníval, že by jeho konání mělo na posmrtný život zesnulého nějaký dopad. Preferována byla jednoduchost obřadu, ideálně v úzkém kruhu rodiny, za zcela zbytečný ho považovali pouze dva informátoři ze třiceti. Kritika obřadů obecně se týkala čtyř oblastí: teatrálnost, nadměrné emocionální zatížení pozůstalých, ekonomická nákladnost pohřbů a nedostatek jejich smyslu.

Pohřeb není dotazovanými vnímán ani jako příležitost vyjá- 


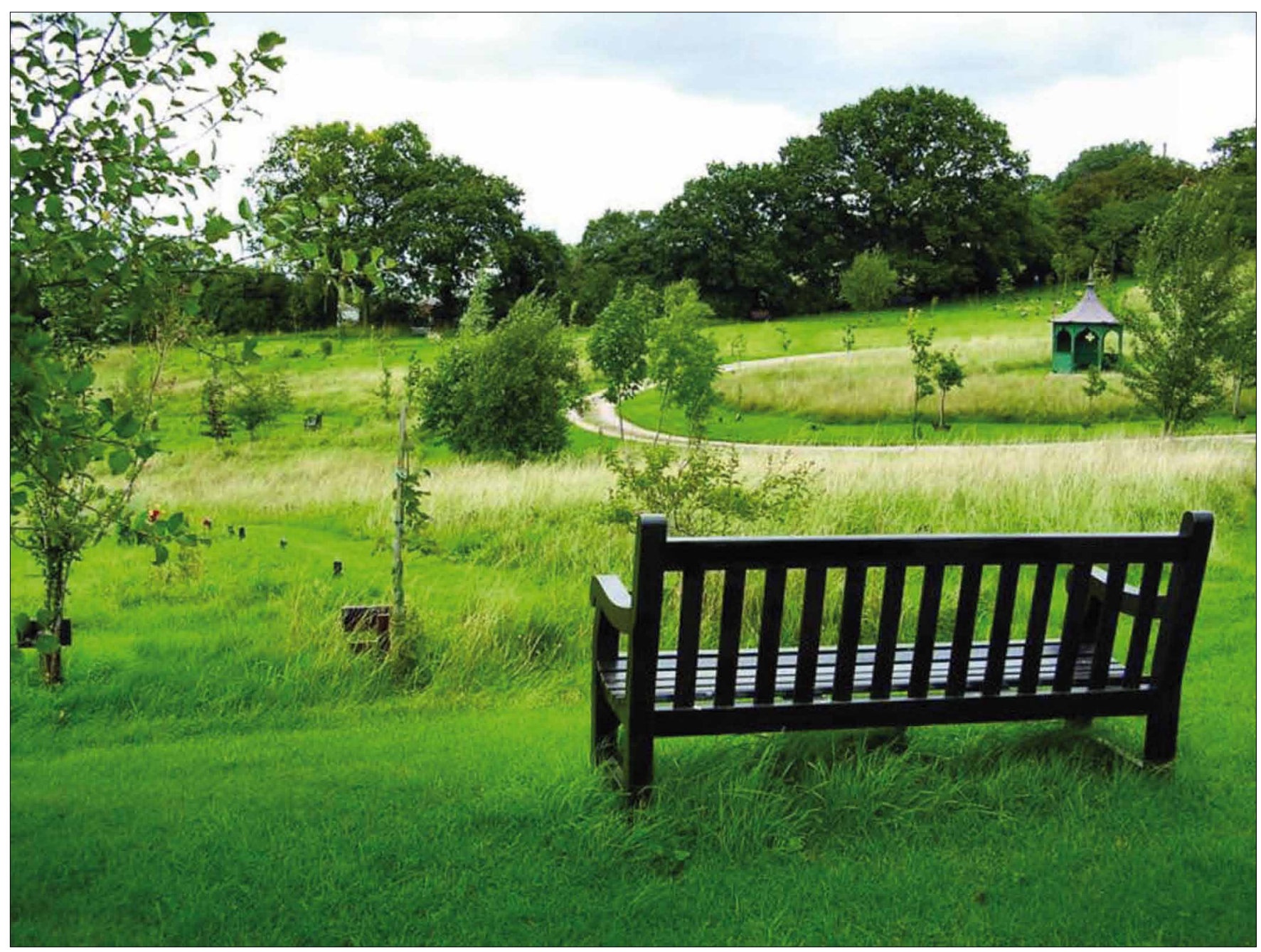

Obr. 2. Př́rodní hřbitov Westall Park, Velká Británie. Zdroj: htttp://www.funeralservicesguide.com./adverts_pics/Image_2199_3.jpg

dřit podporu (nejen skrze kondolenci) nejbližším pozůstalým. Z psychologického hlediska je to přesně naopak, pohřeb je považován za př́ležitost vyjádřit soustrast s pozůstalými a poskytnout jim útěchu, posílit pocit vzájemnosti (Nešporová 2013, 206; Špatenková et al. 2014, 166). Někdy obřad chybí, protože si ho nepřál zesnulý, za čím může stát nespokojenost s podobou současného obřadu a snaha nezatěžovat blízké s jeho zařizováním. Zároveň dnes pozůstalí nepocitují tlak společnosti na uspořádání pohřbu a okolí se o jejich novém statutu většinou dozvídá z parte (Špatenková et al. 2014, 226). Bez smysluplného rituálu po ztrátě blízkého člověka ztrácí moderní člověk schopnost čelit jak vlastní smrtelnosti, tak smrti svých blízkých (Přidalová 2008, 354). Zároveň takovýto prázdný prostor vybízí k vytvoření nových rituálů, které by pozůstalým dávaly smysl (Špatenková et al. 2014, 169). Zaměstnanci pohřebních služeb $\mathrm{v}$ jednom $\mathrm{z}$ akademických výzkumů vyjádřili názor, že se jim nezdá vhodné přicházet s novinkami a jejich nabídka odráží poptávku klientů (Kostelníková 2012, 52). Pak se zde naskýtá otázka, jestli nevznikla poněkud patová situace, kdy obě strany od sebe vzájemně tiše očekávají větší aktivitu. Pozůstalí se v důsledku zastaralé nabídky pohřebních služeb odklánějí od klasického rozloučení a pohřební služby $\mathrm{v}$ důsledku nevyřčených přání pozůstalých neinovují, případně nevědí jak svou nabídku formovat. Od dialogu může pozůstalé odrazovat i netransparentní fungování těchto služeb a společenské zvýrazňování pouze negativních zpráv, které se v této sféře objevují (Kostelníková 2012, 53). Nepříznivé naladění vůči pohřebnictví podporuje také složité emoční rozpoložení po ztrátě blízké osoby. To by mohlo být eliminováno otevřeným a odpovědným přístupem $\mathrm{k}$ posledním věcem. Získáváním informací a plánováním ještě předtím, než jsou tyto služby reálně potřeba.

\section{PŘÍRODNÍ POHŘEBNICTVÍ}

Hnutí přírodního pohřebnictví, které vzniklo ve Velké Británii v 90. letech minulého století, nahlíží na smrt jako na přirozenou součást koloběhu života a vnáší do konzervativní oblasti pohřebnictví důraz na udržitelnost a šetrnost k prostředí. Prrírodní hřbitovy, které mají podobu louky (obr. 2), lesa či třeba háje dnes nalezneme také v Německu, Holandsku, USA 
nebo i v České republice. Pozorování proměn přírodního prostředí vybízí k pochopení smrti jako nevyhnutné a přirozené součásti přírody, přijímání její cyklické povahy a hledání paralel v lidské existenci (Špatenková et al. 2014, 279). Na přírodních hřbitovech, kde je atmosféra méně formální v porovnání s klasickými hřbitovy jsou běžné i pikniky či uvolněnější chování dětí (Davies, Rumble 2012, 51).

Podle Daviese $(2007,88,91)$ je dnes ekologie podobnou sjednocující perspektivou, jakou bývalo kdysi náboženství, ovlivnuující jak vědu či filosofii, tak etiku nebo politiku. Takovéto pojetí smrti může být obecně vnímáno jako něco opravdového, kdy nesehrává roli ani představa o posmrtném životě, ani vzpomínky pozůstalých, ale tělo se stává součástí většího celku, prírody.

Při tvorbě obřadů $\mathrm{v}$ př́rodním pohřebnictví sehráváji důležitou roli prání zesnulého, pokud je za života vyslovil nebo přání pozůstalých a jejich aktivní zapojení do příprav. Takové rozloučení je pak pro pozůstalé smysluplnější a osobnější (Špatenková et al. 2014, 281; Nešporová 2013, 206). Vlastními silami a z vlastních zdrojů můžou pozůstalí zabezpečit například květinovou výzdobu, občerstvení, smuteční řeč, hudební doprovod nebo i sestrojit rakev či urnu.

Princip svépomocné organizace obřadů není vázán pouze na přírodní pohřebnictví a může být uplatněn i při klasickém rozloučení. Walter $(1990,256)$ vidí ve svépomocnosti také snahu lidí vymezit se vůči masové produkci konzumní společnosti. Konec konců, př́rodní pohřebnictví vzniklo ve Velké Británii právě v reakci na měnící se hodnoty a preference lidí týkající se jejich posledních věcí. Kritika podoby obřadů posledního rozloučení se již několik let objevuje i v našem prostředí a proto lze předpokládat, že přírodní pohřebnictví se adaptuje i zde (Špatenková et al. 2014, 282).

Př́rodní hřbitovy jsou typické také svou duchovní otevřeností, proto zde můžou vznikat jak nábožensky orientované, tak sekulární obřady.

\section{ZÁVĚREM}

Dnešní postavení pozůstalých ve společnosti je v mnoha ohledech složité. Vyrovnávají se se ztrátou blízkého člověka, jejich okolí neví, jak jim pomoci a často oni sami pomoc odmítají. Navzdory tomu nejčastější formou pomoci ještě stále zůstává neformální pomoc, kdy pozůstalý překonává ztrátu vlastními silami nebo se obrací na své blízké či na svépomocné skupiny. Citlivější přístup k pozůstalým se začíná zdůrazňovat i v pomáhajících profesích a důležitost této pomoci odráží i vznik samostatné profesní kvalifikace.

Obřad posledního rozloučení dnes sehrává důležitou roli především pro pozůstalé a jeho absence negativně ovlivňuje vyrovnávání se se ztrátou zemřelého (Špatenková et al. 2014, $166,169)$. Naopak rituál vytvořený oficiální cestou nebo svépomocně, který dává pozůstalým smysl a naplňuje jejich očekávání a potřeby, zároveň pomáhá předcházet komplikacím v truchlení a celý jeho proces zmírňuje.

Pohřební služby se orientují spíše na udržení standardu než na vytvoření takového obřadu, který by byl smysluplný především pro pozůstalé. $\mathrm{V}$ řadách psychologů či sociologů se $\mathrm{v}$ tomto kontextu objevuje apel na větší zapojení pozůstalých do př́prav obřadu, které by přidalo na jeho osobitosti a smysluplnosti. At již na klasickém nebo prrírodním hřbitově, v obřadní síni krematoria, či v kostele.

Proto je možno řada na samotných pozůstalých, aby se svou vlastní aktivitou proměnili $\mathrm{v}$ kontextu obřadu $\mathrm{z}$ pasivních diváků na kreativní tvůrce.

\section{LITERATURA}

Ariès, Philippe (2000): Dějiny smrti. Praha: Argo.

Davies, Douglas J. (2007): Stručné dějiny smrti. Praha: VOLVOX GLOBATOR

Davies, Douglas J. - Rumble, Hannah (2012): Natural Burial: Traditional Secular Spiritualities and Funeral Innovation. Bloomsbury Academic.

Elias, Norbert (1998): O osamělosti umírajících v našich dnech. Praha: Nakladatelství Franze Kafky

Gorer, Geoffrey (1955): Pornography of death. Encounter, Vol. 5, No. 4., 49-52.

Kast, Verena (2015): Truchlení. Praha: Portál.

Kostelníková, Michaela (2012): Absence pohřebních obřadů $v$ České republice: př́padová studie z Brna. Diplomová práce. Brno: Katedra sociologie, Fakulta sociálních studií, Masarykova univerzita.

Kupka, Martin (2014): Psychosociální aspekty paliativní péče. Praha: Grada Publishing.

Maiello, Giuseppe (2005) Současné pohřební rituály v českých zemích na příkladu krematorií v Praze-Strašnicích, Zlíně a Plzni. Český lid, č. 1, 35-47.

Mareš, Jiří (2012): Posttraumatický rozvoj člověka. Praha: Grada Publishing.

Nešporová, Olga (2013): O smrti a pohřbívání. Brno: Centrum pro studium demokracie a kultury.

Přidalová, Marie (2008): Proč je moderní smrt tabu? Sociologický časopis, Vol. 34 , No. 3, 347-361.

Rychlíková, Lucie (2014): Pracovníci pohřebních služeb jako součást formalizované péče o pozůstalé v České republice. Diplomová práce. Brno: Katedra sociální politiky a sociální práce, Fakulta sociálních studií, Masarykova univerzita.

Stejskal, David - Šejvl, Jaroslav (2011): Pohřbívání a hřbitovy. Praha: Wolters Kluwer ČR, a.s.

Suchánska, Monika (2014): Př́rodní pohřebnictví - současný stav a další možnosti v českém prostředí. Diplomová práce. Brno: Ústav antropologie, Přírodovědecká fakulta, Masarykova univerzita.

Sutcliffe, Pauline -Tufnell, Guinevere - Cornish, Ursula (1998): Working with the dying and bereaved. London: MACMILLAN PRESS LTD.

Šiklová, Jiřina (2013): Vyhoštená smrt. Praha: Kalich.

Špatenková, Naděžda (2013): Poradenství pro pozůstalé. Praha: Grada Publishing.

Špatenková et al. (2014): O posledních věcech člověka. Vybrané kapitoly $z$ thanatologie. Praha: Galén.

Walter, Tony (1990): Funerals and how to improve them. Kent: Hodder \& Stoughton.

Yoder, Lonnie (1986): The funeral meal: A significant funerary ritual. Journal of Religion and Health, Vol. 25, No. 2, 149-160.

\section{AUTORKA}

Monika Suchánska, Mgr., doktorandka na Ústavu antropologie Př́irodovědecké fakulty Masarykovy univerzity $\mathrm{v}$ Brně, kde se věnuje tématu smrti, zejména fenoménu prrírodního pohřebnictví, o kterém napsala bakalářskou a magisterskou práci. $\mathrm{V}$ dalším výzkumu se soustředuje na svépomocné pohřby. Je spoluzakladatelkou prvního př́rodního hřbitova v České republice a neziskové organizace Ke kořenům, která se snaží o adaptaci prírodního pohřebnictví v českém prostředí a zároveň rozvíjí osvětu v oblasti pohřebnictví obecně. 